\title{
Front Matter: Volume 9617
}

, "Front Matter: Volume 9617," Proc. SPIE 9617, Unconventional Imaging and Wavefront Sensing 2015, 961701 (30 September 2015); doi:

$10.1117 / 12.2218103$

SPIE Event: SPIE Optical Engineering + Applications, 2015, San Diego, California, SPIE. United States 


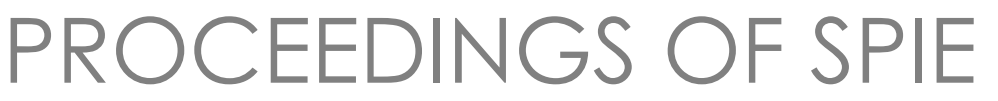

\section{Unconventional Imaging and Wavefront Sensing 2015}

Jean J. Dolne

Thomas J. Karr

Victor L. Gamiz

Editors

12-13 August 2015

San Diego, California, United States

Sponsored and Published by

SPIE 
The papers in this volume were part of the technical conference cited on the cover and title page. Papers were selected and subject to review by the editors and conference program committee. Some conference presentations may not be available for publication. Additional papers and presentation recordings may be available online in the SPIE Digital Library at SPIEDigitallibrary.org.

The papers reflect the work and thoughts of the authors and are published herein as submitted. The publisher is not responsible for the validity of the information or for any outcomes resulting from reliance thereon.

Please use the following format to cite material from these proceedings:

Author(s), "Title of Paper," in Unconventional Imaging and Wavefront Sensing 2015, edited by Jean J. Dolne, Thomas J. Karr, Victor L. Gamiz, Proceedings of SPIE Vol. 9617 (SPIE, Bellingham, WA, 2015) Six-digit Article CID Number.

ISSN: 0277-786X

ISSN: 1996-756X (electronic)

ISBN: 9781628417838

Published by

SPIE

P.O. Box 10, Bellingham, Washington 98227-0010 USA

Telephone +1 3606763290 (Pacific Time) · Fax +1 3606471445

SPIE.org

Copyright (C) 2015, Society of Photo-Optical Instrumentation Engineers.

Copying of material in this book for internal or personal use, or for the internal or personal use of specific clients, beyond the fair use provisions granted by the U.S. Copyright Law is authorized by SPIE subject to payment of copying fees. The Transactional Reporting Service base fee for this volume is $\$ 18.00$ per article (or portion thereof), which should be paid directly to the Copyright Clearance Center (CCC), 222 Rosewood Drive, Danvers, MA 01923. Payment may also be made electronically through CCC Online at copyright.com. Other copying for republication, resale, advertising or promotion, or any form of systematic or multiple reproduction of any material in this book is prohibited except with permission in writing from the publisher. The CCC fee code is 0277-786X/15/\$18.00.

Printed in the United States of America.

Publication of record for individual papers is online in the SPIE Digital Library.

\section{SPIE. DIGITAL}

Paper Numbering: Proceedings of SPIE follow an e-First publication model. A unique citation identifier (CID) number is assigned to each article at the time of publication. Utilization of CIDs allows articles to be fully citable as soon as they are published online, and connects the same identifier to all online and print versions of the publication. SPIE uses a six-digit CID article numbering system structured as follows:

- The first four digits correspond to the SPIE volume number.

- The last two digits indicate publication order within the volume using a Base 36 numbering system employing both numerals and letters. These two-number sets start with 00, 01, 02, 03, 04, $05,06,07,08,09,0 A, 0 B \ldots$ OZ, followed by 10-1Z, 20-2Z, etc. The CID Number appears on each page of the manuscript. 


\title{
Contents
}

\author{
$\checkmark$ Authors \\ vii Conference Committee
}

\section{SESSION 1 WAVEFRONT SENSING AND IMAGING}

961702 Multiconjugate adaptive optics (MCAO): analysis and assessment [9617-1]

961703 Wavefront-sensor tomography for measuring spatial coherence [9617-2]

961704 Three-dimensional polarimetric imaging in a snapshot [9617-27]

961705 Digital holography wave-front sensing in the presence of strong atmospheric turbulence and thermal blooming [9617-5]

961706 The real-time atmospheric turbulence modeling and compensation with the use of adaptive optics [9617-6]

\section{SESSION 2 COMPUTATIONAL AND INTERFEROMETRIC IMAGING}

961708 Laboratory validation of a sparse aperture image quality model [9617-8]

961709 Multiple-baseline detection of a geostationary satellite with the Navy Precision Optical Interferometer [9617-9]

\section{SESSION 3 ACTIVE IMAGING AND BEAM SHAPING}

9617 OB Remote sensing solution using 3D flash LADAR for automated control of aircraft [9617-11]

9617 OC Experimental method of generating electromagnetic Gaussian Schell-model beams [9617-12]

9617 OD Laser beam propagation and wavefront correction in turbid media [9617-13]

\section{SESSION 4 SPECTRAL AND GHOST IMAGING}

9617 OE Metal-oxide-semiconductor photocapacitor for sensing surface plasmon polaritons [9617-14] 
9617 OG Development of an ELT XAO testbed using a Mach-Zehnder wavefront sensor: calibration of the deformable mirror [9617-4]

9617 Ol Preliminary study on the direct detection of phase coded signal for ranging in ladar [9617-17]

9617 0J Imaging signal-to-noise ratio of synthetic aperture ladar [9617-18]

9617 OK Improvement of the signal-to-noise ratio in static-mode down-looking synthetic aperture imaging ladar [9617-19]

$9617 \mathrm{OL}$ Measurement of polarization parameters of the targets in synthetic aperture imaging ladar [9617-21]

9617 OM A balanced APD photodetection technology for large field of view coherent receiver [9617-22]

9617 ON Resampling technique in the orthogonal direction for down-looking Synthetic Aperture Imaging Ladar [9617-23]

961700 A demonstrator of all-optronic multifunctional down-looking synthetic aperture ladar [9617-24]

9617 OP Dual-mode photosensitive arrays based on integration of liquid crystal microlenses and CMOS sensors for obtaining intensity images and wavefronts [9617-25] 


\section{Authors}

Numbers in the index correspond to the last two digits of the six-digit citation identifier (CID) article numbering system used in Proceedings of SPIE. The first four digits reflect the volume number. Base 36 numbering is employed for the last two digits and indicates the order of articles within the volume. Numbers start with 00, 01, 02, 03, 04, 05, 06, 07, 08, 09, OA, OB...0Z, followed by 10-12, 20-2Z, etc.

Adjali, Louisa, OG

Armstrong, J. Thomas, 09

Baines, Ellyn K., 09

Basu, Santasri, OC

Benson, James A., 09

Borsoni, Gilles, 06, OD

Burwell, Alan C., OB

Byalko, Alexander, OD

Cai, Guangyu, OI, OK, OM, ON

Cargill, Daniel S., 05

Clark, James H., III, 09

Cleary, Justin W., OE

Delacroix, Christian, OG

Dragulin, Ivan $V_{\text {., }} 05$

Fuka, Jennifer A., OB

Galaktionov, llya, OD

Gray, Stephen W., OB

Gridley, Matthew J., OC

Hou, Peipei, OL

Hradil, Zdenek, 03

Hubbard, Mason J., OB

Hutter, Donald J., 09

Hyde, Milo W., IV, OC

Ishigami, Masa, OE

Jia, Yucheng, 0 I

Jones, Katharine J., 02

Khalilzade-Rezaie, Farnood, OE

Kudryashov, Alexis, 06, OD

Langlois, Maud P., OG

Leger, Jonathan, OG

Lei, Yu, OP

Li, Baoliang, OM

Li, Guangyuan, OI, ON

Liu, Liren, OI, OJ, OK, OL, OM, ON, 00

Lodge, Michael, OE

Loupias, Magali, OG

Lu, Wei, OL, OO

Lu, Zhiyong, OK, OL, ON, $0 \mathrm{O}$

Lylova, Anna, 06

Ma, Xiaoping, OL

McKeown, Donald M., 08

Motka, Libor, 03

Nader, Nima, OE

Nath, Janardan, $\mathrm{OE}$

Neff, Brian J., OB

Panjwani, Deep, OE

Peale, Robert E., OE

Prasad, Sudhakar, 04

Rehacek, Jaroslav, 03
Restaino, Sergio R., 09

Salvaggio, Philip S., 08

Sánchez-Soto, Luis L., 03

Schenkel, Joseph W., OB

Schmitt, Henrique R., 09

Schott, John R., 08

Sheldakova, Julia, 06, OD

Smith, Christian W., OE

Spencer, Mark F., 05, 0C

Steinbock, Michael J., 05

Stoklasa, Bohumil, 03

Sun, Jianfeng, OI, OK, OL, OM, ON, 00

Sun, Zhiwei, OL, ON, 00

Tallon, Michel, OG

Thiébaut, Eric, OG

Tong, Qing, OP

Vangala, Shiva, OE

Wang, Lijuan, 00

Xie, Changsheng, OP

Xu, Qian, OL

Yannuzzi, Mark, OE

Yu, Zhixian, 04

Zavala, Robert T., 09

Zhang, Guo, Ol, OM

Zhang, Ning, OI, OK, ON, $0 \mathrm{O}$

Zhang, Xinyu, OP

Zhou, Yu, OK, OM 
Proc. of SPIE Vol. $9617961701-6$

Downloaded From: https://www.spiedigitallibrary.org/conference-proceedings-of-spie on 26 Apr 2023 Terms of Use: https://www.spiedigitallibrary.org/terms-of-use 


\section{Conference Committee}

Program Track Chairs

Stephen M. Hammel, Space and Naval Warfare Systems Command

(United States)

Alexander M. J. van Eijk, TNO Defence, Security and Safety

(Netherlands)

Conference Chairs

Jean J. Dolne, The Boeing Company (United States)

Thomas J. Karr, Defense Advanced Research Projects Agency (United States)

Victor L. Gamiz, Air Force Research Laboratory (United States)

Conference Co-chair

David C. Dayton, Applied Technology Associates (United States)

Conference Program Committee

Stephen C. Cain, Air Force Institute of Technology (United States) James Fienup, University of Rochester (United States)

Wes D. Freiwald, Pacific Defense Solutions, LLC (United States)

Richard B. Holmes, Boeing LTS Inc. (United States)

Liren Liu, Shanghai Institute of Optics and Fine Mechanics (China)

Zhaowei Liu, University of California, San Diego (United States)

Sergio R. Restaino, U.S. Naval Research Laboratory (United States)

Michael C. Roggemann, Michigan Technological University

(United States)

Robert K. Tyson, The University of North Carolina at Charlotte

(United States)

David G. Voelz, New Mexico State University (United States)

Session Chairs

1 Wavefront Sensing and Imaging

David C. Dayton, Applied Technology Associates (United States)

2 Computational and Interferometric Imaging

Jean J. Dolne, The Boeing Company (United States) 
3 Active Imaging and Beam Shaping

Victor L. Gamiz, Air Force Research Laboratory (United States)

4 Spectral and Ghost Imaging

Thomas J. Karr, Defense Advanced Research Projects Agency (United States) 